\author{
Ludvík Drímal* \\ Charles University in Prague, Czech Republic
}

\title{
Catechesis in Today's Czech Family
}

\section{Introduction}

At present, the role of the family is taking on a greater significance in the Czech Republic. The issue is related, among other things, to the postmodern context, where the majority of unbelievers in society cast doubt on traditional values. Believers feel apprehensive about this and therefore they keep in mind the ideas of recent popes, who have commented on the matter.

John Paul II wrote: "At a time in history like the present, special attention must also be given to the pastoral care of the family, particularly when this fundamental institution is experiencing a radical and widespread crisis... it is necessary to ensure that through an ever more complete Gospel formation Christian families show

* LUDVÍK DŘÍMAL - After earning a degree from the Sts. Cyril and Methodius Faculty of Theology in Prague based in Litoměrice, he spent several years in pastoral care. After three years of postgraduate studies at the Faculty of Theology at the UPS in Rome, he earned a licenciate and continued his postgraduate studies until 1997, when he became a doctor of pastoral theology with specialization in catechetics. In 2005, he habilitated at CMFT PU in Olomouc and became a docent of theology (effective from 15th June 2005). The congregation confirmed the fact on 17th November 2005. He has worked as a university lecturer since 1997, first as an assistant professor; since 2005 as a docent of theology at the Sts. Cyril and Methodius Faculty of Theology of the PU in Olomouc. Since 2012, he has worked at the Catholic Theological Faculty of Charles University in Prague. His professional interest is focused on pastoral care, especially Church catechesis in the context of postmoderrn society. He is the author of the monograph 'František Tomášek' as a Catechist for Children and Youth, co-author of the coursebook 'Catechetics' and author of many scientific papers, especially in the field of catechetics. 
convincingly that it is possible to live marriage fully in keeping with God's plan and with the true good of the human person - of the spouses, and of the children who are more fragile" 1 .

It is a fact that Saint Pope John Paul II often declared his belief in the strategic importance of family for the future of mankind and the Church, and he made it a crucial point of his pastoral programme for the Church at the beginning of the third millennium ${ }^{2}$.

The idea was adopted by Pope Benedict XVI who frequently spoke about the family as a "crucial issue that demands of us the maximum pastoral attention... It is deeply rooted in the hearts of the young generations and bears the brunt of many problems, providing support and remedies to situations that would otherwise be desperate. Yet ... families in today's cultural atmosphere are exposed to the many risks and threats with which we are all familiar. The inner frailty and instability of many conjugal unions is combined with the widespread social and cultural tendency to dispute the unique character and special mission of the family founded on marriage" ${ }^{3}$. The theses of both popes most specifically apply to the situation of the family in the socio-cultural milieu of the Czech Republic. This milieu has been described from the perspective of the local Church, especially in the concluding document of the Plenary Council of the Catholic Church in the Czech Republic ${ }^{4}$, and confirmed by famous personalities in the fields of sociology, demography or evolutionary biology ${ }^{5}$.

\section{Context and situation of Czech families in regard to catechesis}

Members of Czech families who receive the sacrament of Baptism and also often the two other sacraments of initiation face, in their catechetical effort, quite a few and huge problems. These problems originate from two complex factors, or are at least closely connected with them:

\footnotetext{
1 Ioannes Paulus II, Novo millenio ineunte, no. 47.

2 This part of the monograph was written within a research project conducted at Charles University in Prague called: PRVOUK 01 "Theology as a way of interpreting history and culture".

3 Address to the participants in the 54th General Assembly of the Italian Episcopal Conference, "L'Osservatore Romano" May 30 (2005), p. 5.

4 Život a poslání křestanů v církvi a ve světě. Závěrečný dokument Plenárního sněmu katolické církve v ČR, Praha 2007, ČBK, no. 266-273 (further on ŽaP).

5 See the interview Vítejte v době postrodinné, “Lidové noviny”, February 23 (2013), p. 6.
} 
- The historical context of church catechesis in Czech and Moravian dioceses during most of the 20th century and subsequent development of catechesis, influenced by this situation during the last 23 years, in the context of church effort to renew the pastoral care of children and youth (i.e. catechesis), especially out of school ${ }^{6}$;

- The socio-cultural milieu in contemporary Czech society, affected by the consequences of secularisation and distinctive religious pluralism ${ }^{7}$.

\subsection{The historical context of catechesis in Czech and Moravian dioceses in the last century and subsequent development during the last 23 years with regard to family catechesis.}

The situation of catechesis in the historical period mentioned above underwent several significant changes. Until the first half of the 20th century, systematic catechesis of children at school could develop to a certain extent. Doubt may be raised about regular family catechesis, since parents relied upon obligatory religious education at school. Nevertheless, there were parents discussing the topics of religious education with their children. In many families in rural areas, especially in Moravia, there had been a tradition of evening common prayer, and eventually participation of the whole family in the Sunday Mass. Celebrating Christian feasts during the liturgical year also contributed to transmitting the fundamental truths of the faith. Many children have grown up in the Christian milieu.

The situation of the population in industrial areas, where The Great Depression in the '30s caused social poverty, was quite different. Life of many families had been so heavily affected by the crisis, that Christian education in these areas was overshadowed by existential worries ${ }^{8}$.

6 See Z. Boháč, K otázce vyučování katolického náboženství, "Via. Časopis pro teologii” I (1968), no. 3, p. 54; A. Opatrný, Pastorační situace u nás, Kostelní Vydří 1996, Karmelitánské nakladatelství; L. Dřímal, Katecheze dètí a mládeže v období první Československé republiky, "Studia theologica" (2003), no. 3, p. 61-68.

7 See Z. Vojtíšek, Češi, víra a polévka s játrovými knedličky. Proč tady uspějí léčitelé, http://zpravy. idnes.cz (19.01.2010); M. Opatrný, Pastorace přítomností v prostředí pohanství a nevíry, "Studia theologica" (2013), no. 1, p. 157-181.

8 See C. Nováková, Dějiny katechese a katechetiky v Čechách a na Moravě, manuscript, volume 2, Praha, Konvent OSU, p. 6. 
During most of the second half of the last century, the Church (i.e. Christian families) lived under a totalitarian regime controlled by the Communist Party. The regime forced the Church to restrict the catechesis of children and youth to school education, while making sure that this milieu remained strictly atheistic. To give an impression of religious freedom, a certain form of catechesis was allowed, yet to a very restricted extent with almost no teaching aids. Those who dared to gather children or youth for catechesis elsewhere, e.g. in a presbytery, were monitored and often persecuted. The consequences of systematic destruction of Christian education have especially affected families. Generations of today's parents have been baptized, though they have no personal experience with Christian education. During the Communist era, only a low percentage of families were able to provide, at least partially, Christian education for their members. If there is a total lack of personal experience of most of today's parents and grandparents or motivation for Christian education, the following serious assertion of the local Church might not be astonishing: "Many baptized parents are, due to insufficient education in their childhood and lacking catechesis of adults, not able to educate their children in a Christian way. Christian education, consequently understood as a process characterized by bearing witness to joyously or at least willingly lived life of faith and by patient dialogue, is extinct in many families of the local Church, or has even never taken place"'.

Fortunately, it is possible to complete the picture with few hopeful facts: during the totalitarian period, there were already families involved in prohibited, therefore secret activities of some religious communities and movements: the Salesians of Don Bosco, the Franciscan and Dominican Orders, or the Focolare and Charismatic Renewal Movements. Through non-official, yet all the more cheerful contacts, parents of these families were able to acquire knowledge of the post-conciliar teaching of the Church in regard to their own catechetical activity. Life in secret communities made it possible to share a fundamental experience of the life of faith and to exchange experiences in the field of Christian education ${ }^{10}$.

\footnotetext{
$9 \quad \check{Z} \mathrm{aP}$, art. 214.

10 General characteristics of the catechetical activity of the Church during the above-mentioned period has been provided by M. Zimmermannová, Vývoj katechetiky $v$ českých zemích $v$ letech 1920-1994. Licentiate thesis defended at KTF UK in Prague 2010, esp. p. 31-35.
} 


\subsection{Notes on today's socio-cultural milieu in regard to families}

It is not my intention to question the existence of many families who live in a firm and faithful union. On the other hand, it must be admitted that the infirmity of spousal union is a characteristic of Czech society today. The situation often contributes to the frailty of the family and endangers the educational mission of parents. There is untreated instability, which is, on the contrary, accepted as a "fact" and often leads to divorce, which is considered the only way out of the crisis.

A divorce mentality weakens marriages and makes individual's weaknesses more dangerous. The temptation "to give up without a struggle" seems to have become more frequent and intensive over the last decades ${ }^{11}$.

There are more aspects contributing to the high divorce rate in the Czech Republic, although they vary in detail in every region. It is possible to mention, for instance, the culture of the ever more secularized milieu, where such characteristic aspects occur as a false notion of freedom, fear of commitment, cohabitation, "banalization of sexuality", as Saint John Paul II expressed, or depressive economic situation, which is sometimes a secondary cause of these split-ups. Lifestyle, fashion, and TV series often question the value of spousal life and spread the impression that the mutual gift of self and acceptance of spouses until death is impossible. Their influence together with the pessimistic and destructured concept of man ${ }^{12}$ undermine, depreciate and discredit the family in favour of other "models" of pseudo-family.

Considerable public opinion in the Czech Republic no longer considers the family based on marriage as a base cell of society and a value which is impossible to live without. In Czech society, there are already concepts of supposed "alternatives" to the family which has been marked as "traditional"13.

11 It follows from the results presented by the Czech Statistical Office that during the years 19932012 the total divorce rate in the Czech Republic rose by about 10\% - see http://www.czso.cz/csu/ redakce.nsf/i/rozvodovost (19.08.2014).

12 See Pontifical Council for the Family. Family, Marriage and "de facto" Unions, art. 44.

13 For the causes of the situation see f.i. J. Zeman, Manželství-rodina-děti, hodnoty, přání a realita, Přednáška na sympóziu o manželství a rodině, Brno, March 12-14, 2004. Available on: http://www. rodiny.cz/publikace/prednasky-vystoupeni-v-mediich (19.08.2014). 


\section{Notes on family catechesis in regard to its renewed identity as a form of the Service of the Word}

The renewed identity of catechesis of any sort, formulated not in one, but various ways by the General Directory for Catechesis ${ }^{14}$, implies the presence of the Christian faith at least at an early stage and incorporation into community life, which is considered the natural environment of catechesis ${ }^{15}$. In the context of this topic, it is possible to almost spontaneously consider for instance the desire of family members for life with God or at least the consciousness of vocation to sainthood and the effort to become a domestic sanctuary of the Church ${ }^{16}$ etc., an assumption of authentic family catechesis. In the context of the above-mentioned situation of families, it is an ideal which only a low percentage of Christian families reflect and try to get closer to. Most families give up, although all of their members have received the sacraments of initiation. The underestimated catechesis of adults in parishes can also be the cause of failure. Many parents do not trust their own ability to transmit the contents of the faith "in the right way". On the part of priests in parishes, pastoral assistants, family centres and their associates, an offer to provide parents with the introduction to Christian education of their children is also rather modest. Some of the programmes of family centres are the first attempts to improve the situation, yet they focus on the natural conditions of receiving and living the faith (e.g. Christian Education in Family ${ }^{17}$ and Course on Effective Parenthood ${ }^{18}$ ).

\footnotetext{
14 See GDC, art. 63; 66-68.

15 See GDC, art. 86; 158.

16 See the decree Apostolicam actuositatem, art. 11. The expression "ecclesia domestica" can be found in LG, art. 11 and in the exhortation of St John Paul II Familiaris consortio, art. 21. For more detailed information on the history of understanding this concept see V. Novotný, Ecclesia domestica: pojem domácí církve v dějinách, "Cesty katecheze” V (2013), no. 1, p. 18-20; no. 2, p. 24-26 and no. 3, p. $8-10$.

17 http://www.rodiny.cz/f/file/Krest_vych_NCR.pdf (19.08.2014).

18 http://efektivnirodicovstvi.webnode.cz/ (19.08.2014).
} 


\subsection{Characteristics of family catechesis}

Family catechesis represents an entirely natural part of Christian education and is a matter of bearing witness and life rather than a question of teaching ${ }^{19}$. It is occasional rather than systematic, while its effect is embedded both in content and form ${ }^{20}$.

\subsubsection{Family as a formative environment}

Family as a primary social group offers children the whole spectrum of impulses and situations in order to form particular values ${ }^{21}$. Children, especially younger ones, accept a value only when they experience it as personally important for the adults in whom they trust -especially parents, grandparents or other relatives.

Catechetics, at the turn of the millennium, has rediscovered the meaning of community as an environment of formation ${ }^{22}$. Especially with regard to our subject, there are two essential elements:

1. Regular contact between people who share a strong emotional bond;

2. Attitude to God (especially on the part of the educator in the faith) sufficiently and openly manifested.

Children need a good example from adults. The plural form is not random: it is of crucial importance for a child to know more than one or two such adults. The example of their mother or father alone, or just grandmother or grandfather, or godmother or godfather is not sufficient, since children experience intimacy differently with their parents, grandparents, or godparents.

A visible example of adults, especially parents, is indispensable to education on all fundamental manifestations of the Christian faith: prayer, liturgical celebration, repentance (discerning good and evil, education of conscience), moral education, service and solidarity with the poor.

19 For more detailed information see f.i. C. Bissoli, La catechesi familiare, in: Andate e insegnate, Leumann (TO) 2002, Elledici, p. 296-300.

20 See GDC, art. 255.

21 H. Pospíšilová, L. Smékalová, Utváření hodnot v dětském věku prostřednictvím životních situací v rodině, in: J. Pospíšil, M. Roubalová (eds.), Mládež a hodnoty, Olomouc 2007, VUP, p. 147.

22 See GDC, art. 253-254; for more detailed information f.i. A. Fossion, Perspektivy katecheze v pluralitní společnosti, "Cesty katecheze” I (2009), no. 2, p. 15-19; or Katechumenát jako inspirativní model každé katecheze, “Cesty katecheze” II (2010), no. 2, p. 23-25. 


\subsubsection{Catechesis in a Czech Christian family depends on the level of maturity of parents' faith}

It is apparent, from the facts mentioned above, that the desired effect of catechesis in Czech Christian families depends and will ever more depend on the catechesis (or education in the faith) of parents, should they be able to educate their children. It will also depend on understanding the identity of parents' catechetical role ${ }^{23}$.

The statement that parents are the first catechists of their children does not mean they should be their private teachers. The effort to transmit faith as a doctrine is not very effective. Moreover, there is a danger of spontaneous identification of the faith with its contents, which are actually transmitted in a manner similar to multiplication tables or grammatical rules. This is not the case of the Christian faith. The contents of the faith, though correct and complete, are not the entire faith. The situation is illustrated by the example of a baptized man with no gift of faith: He will not automatically become a believer by being told of the entire contents of the faith, relevant skills and behaviour patterns.

How to help parents who want to "educate" their children "in the faith"? We may help them by:

- Helping them to know the basic condition of such efforts: It begins with their own life of faith. Those who want to help others to experience an encounter with God definitely need their own clear consciousness of encountering Him. To put it simply, I can help someone to receive the Christian faith, if God is a clear, living "You" for me personally, if I search for Him and perceive Him in my life, if I have places and ways of a living encounter with Him in my own everyday life. If it is my intention f.i. to introduce a child to prayer, it implies the child is a frequent witness to my prayers and experiences them with me. One can serve only with one's own riches ${ }^{24}$.

23 For more detailed information see f.i. D. Emeis, Grundriss der Gemeinde- und Sakramentenkatechese, München 2001, DKV, p. 49-52; U. Montisci, Role rodiny v křestanské iniciaci dètí, "Cesty katecheze" V (2013), no. 3, p. 11-13.

24 There is an agreement on this point between representatives of the Magisterium of the Catholic Church (from the exhortation of Saint John Paul II Familiaris consortio to f.i. Pontificio Consiglio per la Famiglia, La famiglia immagine di Dio, cellula vitale della Chiesa e della società, art. 1 and 4) and the authors of specialized and popular catechetical literature, based on the insights from the field of communication psychology, f.i. S. Giusti, La via italiana alla catechesi familiare. Milano 2008, Paoline. 
- Besides this effort, it is of crucial importance what image of God I have as educator, what is the concrete content of my image of God. It is not sufficient to know that God is close to me, but it is important how I experience the closeness to God. Is he close to me, and yet not "at hand" to fulfil my wishes, or a watchman who can see everything? Due to various "styles" of Christian education in the Czech and Moravian milieu, varied images of God occur among Christians, from the image of God expecting or even demanding appropriate religious efforts to the image of God that is good-natured or easygoing $^{25}$.

The same applies to the connection of catechesis with celebrating the sacrament of Reconciliation: Should a child experience the joy of God's forgiveness, it necessarily implies two aspects:

1. The fact that the child has experienced this joy before, since the parents are able to let their child experience that they have forgiven themselves (it is not sufficient to tell them they have been forgiven; it is necessary to let the child experience it repeatedly).

2. It is of the same importance for children to see their parents, grandparents or other relatives experiencing joy whenever God has forgiven them. However, have the parents ever expressed such a joy? To what extent have they experienced it themselves? To what extent are they capable of this joy? Again, the image of God that the educator has is very important, since only this image radiates from him and influences others ${ }^{26}$.

\subsubsection{Meaning of godparents}

Parents choose for their (young) children godparents, as persons accompanying and supporting children in the life of faith. Choosing a godfather (godmother) is a very delicate affair, since he (she) is the person whose responsibility is "to show the candidates how to practise the Gospel in personal and social life, to sustain the candidates in moments of hesitancy and anxiety, to bear witness, and to guide the candidates' progress in the baptismal life"27.

The service of godparents is mediating. On the one hand, godparents act as representatives of the community of the faithful, to which the catechumen

25 See R. Sauer, Loučení s “dobrým Pánembohem”, “Teologické texty” XXI (2010), no. 2, p. 81-82; Zralost člověka v procesu výchovy, "Cesty katecheze” II (2010), no. 4, p. 24-26.

26 See Ch. Ponsardová, Víra v rodině, Kostelní Vydří 2008, Karmelitánské nakladatelství, p. 153-154.

27 See Rite of Christian Initiation of Adults, art. 11. 
is admitted; on the other hand, they perform the function of a guarantor and representative of the catechumen in the entire community. It is a fact that these functions recede after reception of the catechumen into full communion, but the co-responsibility of godparents for their godchildren's faith and their spiritual accompaniment should continue ${ }^{28}$.

\subsubsection{Catechetical work with adolescents}

If young people, in adolescence, ask their parents religious questions, they do it in a completely new way. Adolescents view the whole field from their own perspective ${ }^{29}$. In general, an adolescent raises a number of objections to the practice or teaching of the Church. To simply reject this criticism, even if it is provocatively expressed, is not honest. This critical view of teenagers represents, for adults, a specific understanding of the reality. It is like the reflection in the mirror which is curved (like a caricature), i.e. it is not partially accurate (correct) but still indicates a very important part of the adolescent's life. It is an opportunity for dialogue and to reflect on our pastoral practice ${ }^{30}$. Intergenerational dialogue has its own typical difficulties, being even intensified by today's rapid development of (especially information) technology. The result is that members of the elder generation, to some extent, do not orient themselves in this world which is so natural for the young generation ${ }^{31}$.

\section{Conclusion}

The specifics of family catechesis consist in:

- sharing of everyday life;

- being carried by strong emotional bonds mutually connecting family members, especially children with parents.

28 See D. Emeis, Grundriss der Gemeinde- und Sakramentenkatechese, München 2001, DKW, p. 89-90; H. Johnová, Ručitel a křestní kmotrovství dospělých, “Cesty katecheze” II (2010), no. 2, p. $18-19$.

29 See f.i. L. Bartůšková, Některé pohledy vývojové psychologie na práci s mladými biřmovanci, "Cesty katecheze" IV (2012), no. 2, p. 15.

30 See ŽaP, art. 187; Morální výchova dospívajících v podmínkách současné společnosti, "Cesty katecheze" IV (2012), no. 3, p. 16-19.

31 See ŽaP, art. 183. 
Family catechesis is original and has a completely indispensable role: it precedes, accompanies and enriches all other forms of catechesis ${ }^{32}$.

In the local Church of the Czech Republic, up to the present day, we perceive a very topical task: to steadily overcome the inherited mentality taking no account of parents and godparents as catechists. At the same time, ever more patience is needed, since the educational activity of today's families is largely restricted by various factors (f.i. many parents' lack of personal experience with religious education, social pressure undermining and weakening the family) or has been plunged into imminent crisis.

There is an ever more urgent need to deliberately and continually help:

- to support the institutions striving for defence and development of family;

- to organize permanent education about the problems of today's family with the participation of lay experts, not only for parents, but also clergy and religious;

- to offer pastoral activities in parishes which can be participated in by the whole family and where sharing of faith experience can take place ${ }^{33}$;

- to learn to share experiences, recommend appropriate literature and spare no expense. It is, indeed, the best investment for the future ${ }^{34}$.

The situation in the Czech Republic is specific, because believers. often hear in their parish. that they are the catechists of their family. Yet, besides prayers on the part of the Church, there is no so strong practical support for this activity.

If the Church would develop the above-mentioned forms of supporting parents as catechists, hope can be raised that they will:

- find more time for their children,

- discover the beauty of communication with children from an early age,

- rediscover their catechetical role in the family,

- feel the need for renewing the contents and manifestations of their own faith, which will support their religious education,

- discover the need of sharing with other believing families in their own parish or surroundings.

Nevertheless, it implies that the local Church will not only encourage the faithful to perform their role of family catechists, but also offer catechetical meetings

32 See Ioannes Paulus II, Catechesi tradendae, art. 68; GDC, art. 226.

33 See f.i. the concept of community catechesis mentioned by A. Fossion, Perspektivy katecheze v pluralitní společnosti, “Cesty katecheze” I (2009), no. 2, p. 16.

34 See Pokoj a dobro. List ČBK k sociálním otázkám v České republice, art. 50; GDC, art. 227. 
specifically focused on practical recommendations, didactic materials, personal sharing among parents, professional advice and spiritual support. I consider the greater engagement in this area, i.e. to care more intensively and specifically for parents as catechists, a decisive step for the better.

\section{Bibliography}

Ioannes Paulus II, Novo millenio ineunte, Czech translation Praha 2001, ČBK.

Sacra Congregatio pro Clericis, Directorium generale pro catechesi, Roma 1997, ed. Libreria Editrice Vaticana.

Bartůšková L., Některé pohledy vývojové psychologie na práci s mladými biřmovanci, "Cesty katecheze" IV (2012), no. 2, p. 15.

Bissoli C., La catechesi familiare, in: Andate e insegnate, Leumann (TO) 2002, ed. Elledici.

Dřímal L., Katecheze dětí a mládeže v období první Československé republiky, "Studia theologica" (2003), no. 3, p. 61-68.

Emeis D., Grundriss der Gemeinde- und Sakramentenkatechese, München 2001, ed. DKV.

Fossion A., Katechumenát jako inspirativní model každé katecheze, "Cesty katecheze” II (2010), no. 2, p. 23-25.

Fossion A., Perspektivy katecheze v pluralitní společnosti, “Cesty katecheze” I (2009), no. 2, p. 15-19.

Giusti S., La via italiana alla catechesi familiare, Milano 2008, ed. Paoline.

Johnová H., Ručitel a křestní kmotrovství dospělých, “Cesty katecheze” II (2010), no. 2, p. 18-19.

Montisci U., Role rodiny v křestanské iniciaci dètí, “Cesty katecheze” V (2013), no. 3, p. 11-13.

Nováková C., Dějiny katechese a katechetiky v Čechách a na Moravě, manuscript, volume 2, Praha, Konvent OSU.

Novotný V., Ecclesia domestica: pojem domácí církve v dějinách, "Cesty katecheze” V (2013), no. 1, p. 18-20; no. 2, p. 24-26 and no. 3, p. 8-10.

Opatrný A., Pastorační situace u nás. Kostelní Vydří 1996, ed. Karmelitánské nakladatelství.

Opatrný M., Pastorace prítomností v prostředí pohanství a nevíry, "Studia theologica" (2013), no. 1, p. 157-181.

Pokoj a dobro. List ČBK k sociálním otázkám v České republice, Praha 2000.

Ponsardová Ch., Víra v rodině, Kostelní Vydří 2008, ed. Karmelitánské nakladatelství.

Pospíšilová H., Smékalová L., Utváření hodnot v dětském věku prostřednictvím životních situací v rodině, in: J. Pospíšil and M. Roubalová (eds.), Mládež a hodnoty, Olomouc 2007, ed. VUP.

Zeman J., Manželství-rodina-děti, hodnoty, přání a realita. Přednáška na sympóziu o manželství a rodině, Brno, March 12-14, 2004. Available on: http://www.rodiny.cz/publikace/prednaskyvystoupeni-v-mediich (19.08.2014). 
Zimmermannová M., Vývoj katechetiky v českých zemích v letech 1920-1994. Licentiate thesis defended at KTF UK in Prague 2010.

Život a poslání křestanů v církvi a ve světě. Závěrečný dokument Plenárního sněmu katolické církve v ČR. Praha 2007, ed. ČBK. 